\title{
Sickle cell disease in Sri Lanka: clinical and molecular basis and the unanswered questions about disease severity
}

Thamal Darshana ${ }^{1 *}$ D, Dayananda Bandara ${ }^{2}$, Upul Nawarathne ${ }^{3}$, Udaya de Silva $^{4}$, Yasinta Costa ${ }^{5}$, Kalavitigoda Pushpakumara ${ }^{6}$, Sumithra Pathirage ${ }^{7}$, Seuwandi Basnayake ${ }^{8}$, Chamila Epa ${ }^{9}$, Pradeepa Dilrukshi ${ }^{10}$, Maheshaka Wijayawardena ${ }^{11}$, Angela A. Anthony ${ }^{12}$, Rexan Rodrigo ${ }^{13}$, Aresha Manamperi ${ }^{14}$, Frances Smith ${ }^{15}$, Angela Allen ${ }^{16}$, Stephan Menzel ${ }^{17}$, David Rees ${ }^{18}$ and Anuja Premawardhena ${ }^{19}$

\begin{abstract}
Background: Though case reports and limited case series of Sickle cell disease in Sri Lanka have been reported previously, no attempt has been made hitherto to undertake a comprehensive genotypic-phenotypic analysis of this "rare" group of patients.

Results: All accessible Sickle cell disease patients, totaling 60, including, 51 Sickle $\beta$-thalassaemia and 9 homozygous sickle patients were enrolled from seven thalassaemia treatment centres between December 2016-March 2019. The majority of patients were of Sinhalese ethnicity $(n=52,86.67 \%)$. Geographically, two prominent clusters were identified and the distribution of Sickle haemoglobin in the island contrasted markedly with the other haemoglobinopathies. 3/ 9 homozygous sickle patients and 3/ 51 Sickle $\beta$-thalassaemia patients were receiving regular transfusion. Joint pain was the commonest clinical symptom among all sickle cell disease patients $(n=39,65.0 \%)$. Dactylitis was significantly more common in homozygous sickle patients compared with the Sickle $\beta$-thalassaemia groups ( $p$ 0.027). Two genetic backgrounds sickle mutation were identified namely, Arab Indian and Benin. Among the regulators of Foetal hemoglobin in Sickle patients of the present study rs1427407 G > T seemed to be the most prominent modifier, with a significant association with Foetal haemoglobin levels ( $p$ 0.04).
\end{abstract}

Conclusions: Overall, the clinical course of the Asian version of Sickle cell disease in Sri Lanka appears to be milder than that described in India.

Keywords: Sickle cell, Sri Lanka, Genetic, Clinical, Severity

\section{Background}

Sickle Cell Disease (SCD) is the collective term for a group of inherited disorders characterized by mutations in the gene encoding the $\beta$-haemoglobin subunit (HBB). The prevalence of the disease is high in sub-Saharan Africa, Middle East, India, Jamaica and Brazil [1]. Sri

\footnotetext{
* Correspondence: darshana@sjp.ac.lk

'Department of Medical Laboratory Sciences, University of Sri Jayewardenepura, Nugegoda, Sri Lanka

Full list of author information is available at the end of the article
}

Lanka is a multi-ethnic country with a population of 20.4 million, comprised of Sinhalese (74.9\%), Tamils (15.2\%), Moors (9.3\%) and several other minor groups [2].

Sickle haemoglobin $(\mathrm{Hb} \mathrm{S})$ was first reported in the country among Sinhalese in 1962 in the Eastern province of the country [3]. Even though Sri Lanka is geographically adjacent to India, where the prevalence of $\mathrm{Hb} \mathrm{S}$ is high, particularly among tribal populations, the prevalence of $\mathrm{Hb} \mathrm{S}$ in Sri Lanka is lower and is confined mainly to coastal areas [4]. No detailed descriptions of SCD in 
Sri Lanka are available in the literature, although there are several reports for some sporadic cases of $\mathrm{SCD}$, including homozygous sickle cell anaemia $(\mathrm{Hb}$ SS), sickle- $\beta$ thalassaemia (SBT) and $\mathrm{Hb}$ SD disease [5-10]. Currently, SCD patients in Sri Lanka are typically treated in either thalassaemia centres or general paediatric or medical wards. A recent island-wide hospital based epidemiological survey of haemoglobinopathies identified 1774 patients with a haemoglobinopathy. 51 of whom were sickle patients (un specified SCD), confirming that SCD is uncommon in Sri Lanka (2.8\%) (51/1774). The same survey identified significant inconsistencies in care of SCD patients between centres [11]. Genetic information including haplotype analysis for SCD in Sri Lanka is scarce, and has been reported for a single patient with SBT [12] only. Hence, in the present study we intend to describe the clinical picture of SCD patients in Sri Lanka, analyze its molecular basis, including the effects of genetic modifiers on the phenotype.

\section{Methods}

\section{Study design and population}

We conducted a cross-sectional study between December 2016 and March 2019 recruiting patients previously diagnosed with SCD from seven thalassaemia centres in Sri Lanka. The thalassaemia centres were located in the districts of Mahara, Kurunegala, Anuradhapura, Hambantota, Monaragala, Ampara and Batticaloa. All SCD patients were eligible for the study and there were no exclusion criteria. All patients were examined by the study physician and clinical details were obtained using a pre-tested interviewer-administered questionnaire. Ethical approval for the study was obtained from Faculty of Medicine, University of Kelaniya, Sri Lanka (P/01/01/2016). Informed written consents form adult SCD patients and assents from the parents of the participating SCD children were obtained before enrollment for the present study.

\section{Haematological and haemoglobin analyses}

A Five ml venous blood sample was collected into EDTA (Ethylenediaminetetraacetic acid) from each participant. Routine haematological measurements were conducted using a Coulter counter Ac•T 5 diff OV (Beckman Coulter, Inc., Brea, California, United States). Haemoglobin phenotype was determined by capillary electrophoresis (CE) using Capillarys 2 flex piercing analyzer (Sebia, France). DNA for genetic analyses was extracted by QIAamp DNA Blood Mini Kit (Qiagen, Hilden, Germany) and stored at $-20^{\circ} \mathrm{C}$ until further use.

\section{Basic genetic analyses}

Classical $\beta$ - globin haplotyping was performed. Six regions around and within the $\beta$ globin gene cluster were amplified by the polymerase chain reaction (PCR), using primers from Integrated DNA Technologies, Inc., Iowa, United States. Primer sequences were those referenced by [13]. PCR products of each patient were treated with appropriate restriction enzymes (from Thermofisher scientific) according to manufactures instructions and the resulting fragments were separated on $2 \%$ agarose gel. Bands were visualized and photographed by UVP BioDoc-It ${ }^{\circ}$ Imaging System. Six polymorphic restriction sites were studied; $5^{\prime}$ to $\varepsilon$ gene by Hind II, $5^{\prime}$ to $\mathrm{G} \gamma$ gene by Xmn I, within IVS 2 of the Gy and Ay genes by Hind III, $3^{\prime}$ to $\psi \beta$ by Hind II, and IVS 2 of the $\beta$ gene by Ava II. When the Restriction Fragment Length Polymorphism (RFLP) pattern was heterozygous, the sickle haplotype was determined based on the assumption that common sickle haplotypes were present [14]. Common $\alpha+$ globin gene deletions (3.7 and $4.2 \mathrm{~kb}$ ) were studied by multiplex GAP polymerase chain reaction [15]. Betathalassaemia mutations of the SBT patients were determined by Amplification Refractory Mutation System (ARMS) [16].

\section{Sequencing analyses of $\mathrm{Hb}$ SS patients}

New generation sequencing (NGS) was done using a customized panel which sequenced 5 regions of the genome of all the $\mathrm{Hb}$ SS patients reported in study including; Chromosome 2 (hg 19 Grch build 37) - chr2:60,575,685 60,753,050, Chromosome 6 (hg 19 Grch build 37) - chr6: 135,281,347 - 135,540,835, Chromosome 11 (hg 19 Grch build 37) - chr11:3,779,641 - 7,224,114, Chromosome 16 (hg 19 Grch build 37) - chr16: 575,307-2,619,179 and Chromosome X (hg 19 GrCh build 37) - chrX:11,253,92211,377,717 using Illumina platform (Illumina Miseq). Variations found were annotated with Integrative Genomic Viewer version 2.6 (Broad Institute) using GRCh37 hg19 - Genome - Assembly by NCBI (National Centre for bio-informatics) as the reference sequence.

\section{Genotyping of Foetal Haemoglobin ( $\mathrm{Hb}$ F) modifiers among SCD patients}

Four known Hb F modifiers (rs1427407 and rs6545816 in BCL11A, rs66650371 in HMIP-2A and rs9402686 in HMIP-2B) were genotyped by Taqman assay real time PCR using Viia 7 Applied Biosystems. One Hb F modifier (rs7482144 in Xmn1-HBG2) was genotyped by RFLP. These $\mathrm{Hb} F$ markers were selected based on their positive association with $\mathrm{Hb} F$ levels in SCD patients suggested by several studies [17-19].

\section{Results}

\section{Basic demographic data}

Between December 2016 and March 2019, 60 SCD patients were recruited for the study. Fifty-one patients $(51 / 60 ; 85 \%)$ were SBT patients and $9(9 / 60 ; 15 \%)$ were 
homozygous Hb SS patients. Homozygosity was confirmed in all 9 patients by typing the sickle mutation rs334 ( $\mathrm{T}>\mathrm{A}$ ) at chr11:5227002 (GRCh38.p12) by NGS. There were 30 male and 30 female participants. Thirtyseven $(72.55 \%)$ SBT patients had IVS 1-5 $(\mathrm{G} \rightarrow \mathrm{C}) \mathrm{mu}-$ tation, 11(21.57\%) had IVS 1-1 (G $\rightarrow$ A) mutation, 2 had CD-16 mutation and one SBT patient had CD 41/42 mutation. Even though IVS $1-5(\mathrm{G} \rightarrow \mathrm{C})$ clinically behaves as an $\beta^{0}$ mutation for all practical purposes SBT patients with IVS $1-5(G \rightarrow C)$ was classified separately as severe $\mathrm{Hb} \mathrm{S} / \beta+$ as it is known to produce some $\mathrm{Hb} A$ $(n=37)$ [20-23]. SBT patients identified with other $\beta$ mutations were all unquestionably severe mutations and were classified as $\mathrm{Hb} \mathrm{S} / \beta^{0}$ type $(n=14)$. SCD patients in the present study were living in 10 out of the 25 districts of Sri Lanka. Geographically, two prominent patient clusters were noted and the Southern cluster comprising Hambantota and Monaragala districts accounting for 27 (45.0\%) SCD patients was the dominant cluster (Fig. 1). The SCD patients comprised of three ethnic groups; 52 $(86.67 \%)$ were Sinhalese, $5(8.33 \%)$ were Moors and 3 (5.0\%) were Tamils. Non-parametric statistical methods were used since data were not normally distributed.

\section{Haematological data}

Basic haematological parameters of those who had not received a blood transfusion in the three months prior to blood sampling are summarized in Table 1.

\section{Clinical findings}

Age at presentation of all SCD patients was highly variable, ranging from 4 months to 55 years (Mean 9.8 years; SD- 11.3 years). Most of the patients $(51.7 \% ; n=31)$ had presented with fever, whilst the next common presenting symptoms were joint pain and abdominal pain $(26.7 \%$; $n=16$ ). Icterus led to identification of the disease in a further 9 (15\%) cases. Six more patients were incidentally diagnosed whilst investigating anaemia. A further three patients were diagnosed during pregnancy (including two $\mathrm{Hb} \mathrm{S} / \beta^{0}$ patients and one severe $\mathrm{Hb} S / \beta+$ patient). Three out of $9(33.33 \%) \mathrm{Hb}$ SS, $1 / 37$ (2.7\%) severe $\mathrm{Hb} \mathrm{S} / \beta+$ and $2 / 14(14.3 \%) \mathrm{Hb} \mathrm{S} / \beta^{0}(p$ 0.012) patients were on regular blood transfusion (defined as $>8$ transfusions/year). Based on clinical records it appeared that blood transfusions had mostly been given when haemoglobin concentration of the patient fell to $6 \mathrm{~g} / \mathrm{dl}$ or less, although this could not be ascertained with certainty. Incidentally, $12(23.53 \%)$ of SBT patients ( 7 severe $\mathrm{Hb} S / \beta+$ and $5 \mathrm{Hb} \mathrm{S} / \beta^{0}$ patients) never had any transfusion in their lifetime.

Clinical features of $\mathrm{Hb} \mathrm{SS}$, severe $\mathrm{Hb} \mathrm{S} / \beta+$ and $\mathrm{Hb} \mathrm{S/}$ $\beta^{0}$ and patients are summarized in Table 2. Joint pains were the most common clinical symptom observed among all SCD patients. Ischemic cerebrovascular event had occurred in one severe $\mathrm{Hb} S / \beta+$ and one $\mathrm{Hb} \mathrm{SS}$ patient. Similarly, avascular necrosis of the hip was present in one $\mathrm{Hb} S \mathrm{~S}$ patient and one severe $\mathrm{Hb} S / \beta+$ patient. Fisher's exact test showed that the incidence of dactylitis was the only clinical feature which was significantly different between $\mathrm{Hb} \mathrm{SS}$, severe $\mathrm{Hb} \mathrm{S} / \beta+$ and $\mathrm{Hb}$ $S / \beta^{0}$ patients $(p$ 0.027). Nevertheless, none of the clinical features were significantly different between severe $\mathrm{Hb}$ $\mathrm{S} / \beta+$ and $\mathrm{Hb} S / \beta^{0}$ patients. Genotype-phenotype associations were also assessed separately between $\mathrm{Hb}$ SS, severe $\mathrm{Hb} S / \beta+$ and $\mathrm{Hb} S / \beta^{0}$ patients those who were on regular transfusions and those who were not. Nevertheless, Fisher's exact test was unable to find any difference between the patients in the two transfusion categories. Splenectomy had been carried out in 1 / $9 \mathrm{Hb}$ SS and 4/ 51 severe $\mathrm{Hb} S / \beta+$ patients. The exact reason for splenectomy and its justification could not be deduced from the clinical records. Four of the splenectomized patients had undergone the surgery before the age of 20 years. Forty-one SCD patients $(6 \mathrm{Hb} S \mathrm{~S}, 23$ severe $\mathrm{Hb} S / \beta+$ and $12 \mathrm{Hb} \mathrm{S} / \beta^{0}$ patients) (68.3\%) in our series had a history of at least one pain event (Joint/Abdominal/Chest) in their lifetime, while 19 SCD patients including three $\mathrm{Hb}$ SS individuals had not experienced any pain events. Cold weather $(33.33 \%, n=20)$ was the most frequently identified precipitating factor for pain events among SCD individuals, followed by infections $(26.32 \%, n=15)$. Thirteen (21.66\%) SCD patients who had pain crisis reported no obvious precipitant factor for pain events. At the time of data collection 26 (43.33\%) SCD patients were taking Hydroxyurea. Nineteen (31.67\%) SCD patients were on Folic acid only. Twenty-eight (48.7\%) SCD patients were on penicillin prophylaxis. Six SCD patients $(10 \%)$ were not on any medication.

\section{Genetic findings}

Gap PCR for common $\alpha+$ gene deletions found only 4 (6.67\%) SBT patients with $3.7 \mathrm{~kb}$ deletions. None of the SCD patients had the $4.2 \mathrm{~kb} \alpha$ gene deletion.

Haplotyping by traditional RFLP showed that the sickle mutation occurred on two main beta globin haplotypes in Sri Lanka. Namely Arab-Indian (AI) and Benin. Out of $18 \beta$ globin haplotypes among the $9 \mathrm{Hb}$ SS patients, 14 were AI haplotype and 4 were Benin haplotype. Presence of AI haplotype and Benin haplotype in Sri Lanka was confirmed with NGS by typing 4 different SNPs (rs3834466, rs28440105, rs10128556 and rs968857) in $9 \mathrm{Hb}$ SS patients as described previously [27]. When looking at the genetic variants that moderate $\mathrm{Hb} F$ levels, rs6545816 in BCL11A was found at the highest allele frequency (88\%) followed by rs7482144 in Xmn I-HBG2 (47\%) (Table 3). Allelic discrimination plot of rs6545816 is shown in Fig. 2. 


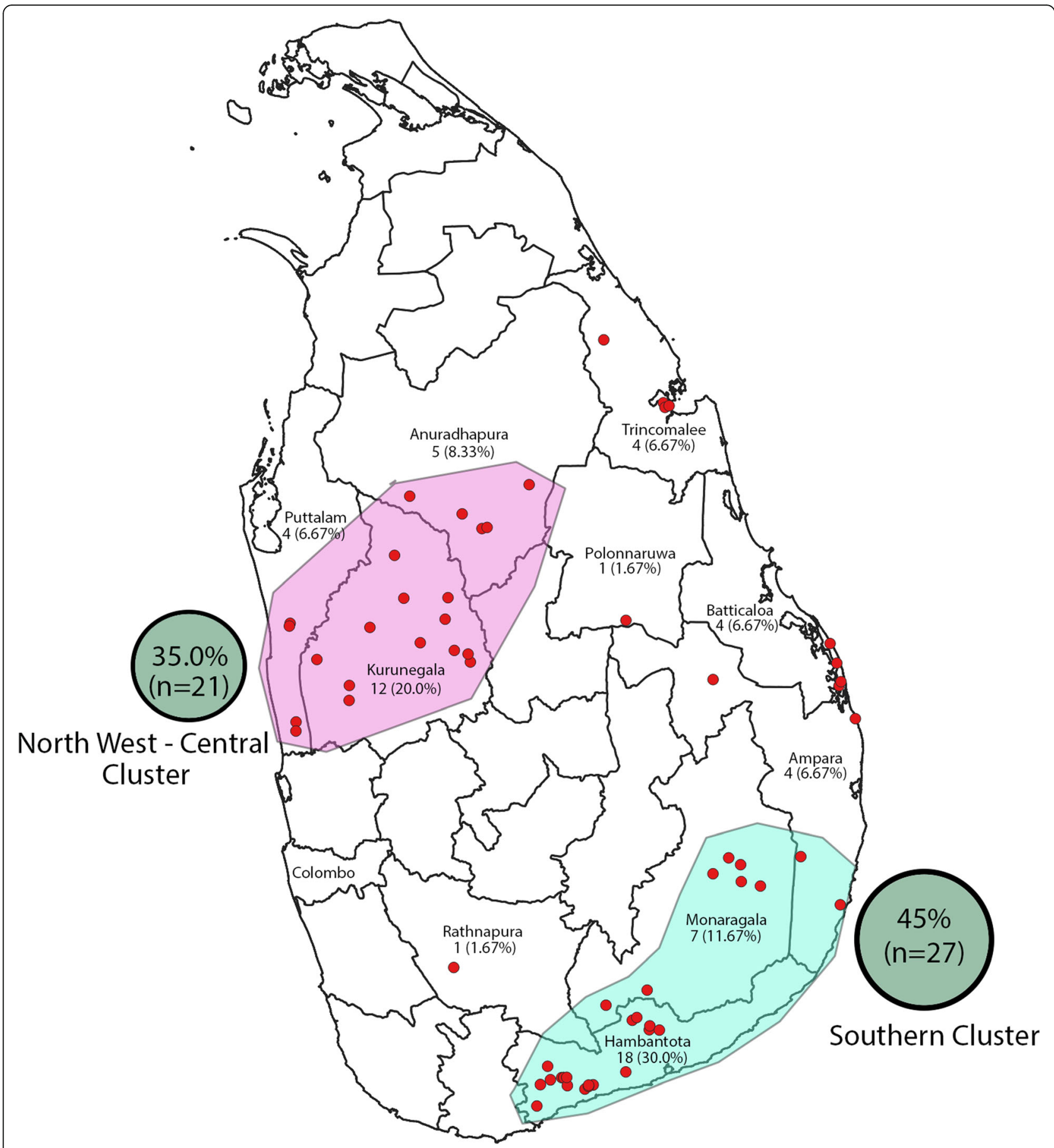

Fig. 1 Locations from which SCD patients were reported in present study (each dot represents one patient)

\section{Discussion}

Our study is the first description of the genotypic and phenotypic associations of SCD in Sri Lanka. Haplotype data in our present study sheds new light on the genetic background of $\mathrm{Hb} \mathrm{S}$ in Sri Lanka. Both $\mathrm{AI}$ and Benin haplotypes of $\mathrm{Hb} \mathrm{S}$ are common in Saudi Arabia [28, 29]. The presence of $\mathrm{AI}$ and Benin haplotypes of $\mathrm{Hb} \mathrm{S}$ in Sri Lanka suggests that occurrence of $\mathrm{Hb} \mathrm{S}$ in Sri Lanka is more likely to have originated from Arab migrations than African settlings: Historical records also indicate the existence of Arab settlements near coastal towns of Beruwala, Colombo, Chilaw, Galle, Mannar, Puttalam and Trincomalee by ninth century A.D. [30]. In the present study most of the SCD patients recruited were living fairly close to some of above-mentioned coastal areas. 


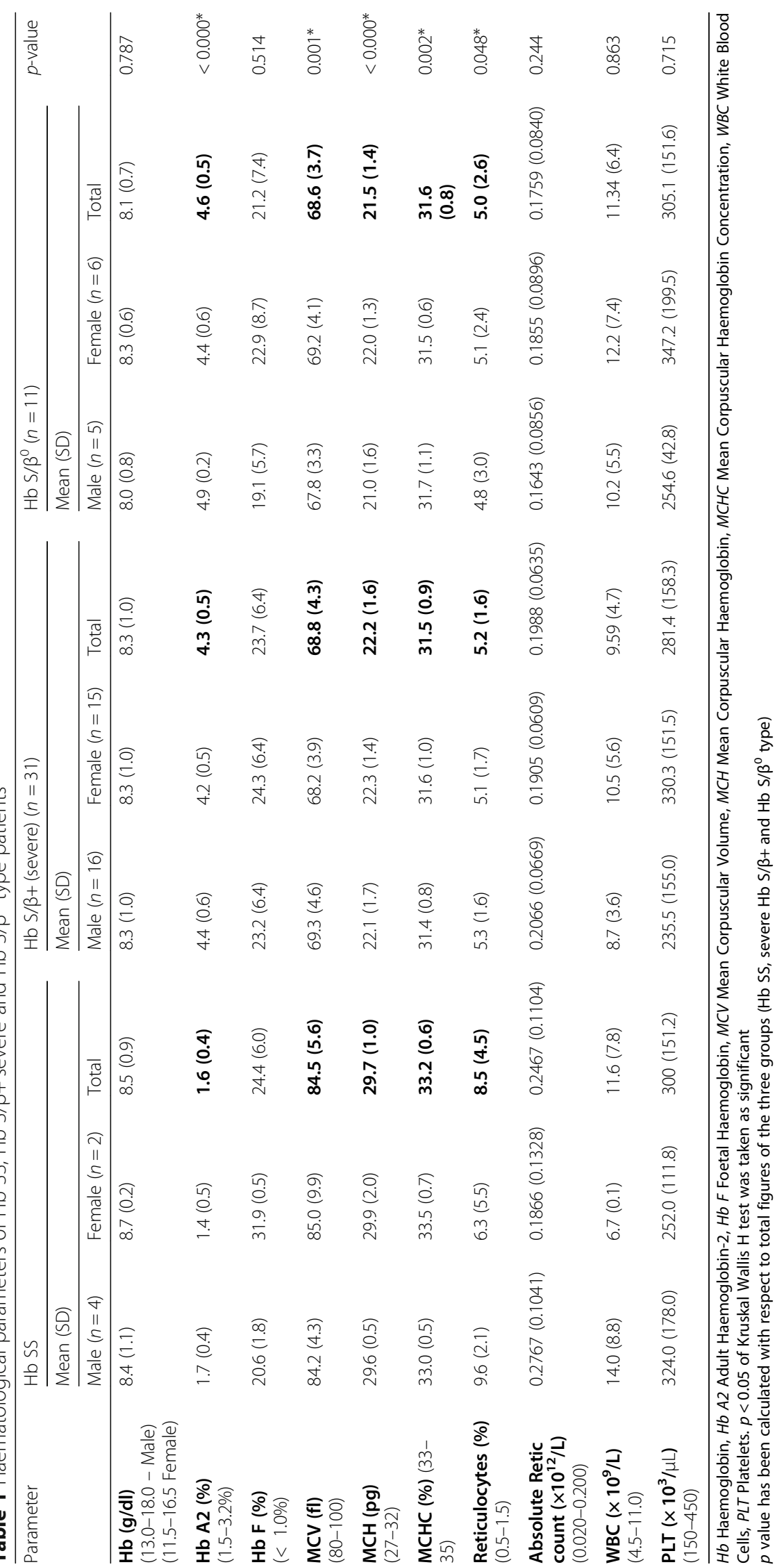


Table 2 Summary of clinical features observed between severe $\mathrm{Hb} S / \beta+, \mathrm{Hb} S / \beta^{0}$ and $\mathrm{Hb}$ SS groups

\begin{tabular}{|c|c|c|c|c|c|c|}
\hline Clinical feature/Complication & $\begin{array}{l}\text { severe } \mathrm{Hb} S / \beta+ \\
\text { group } \\
n=37\end{array}$ & $\begin{array}{l}\mathrm{Hb} \mathrm{S} / \beta^{0} \text { group } \\
n=14\end{array}$ & $\begin{array}{l}\text { Hb SS group } \\
n=9\end{array}$ & $\begin{array}{l}\text { Cumulative Figure } \\
N=60\end{array}$ & $\begin{array}{l}p \text { value }{ }^{1} \text { between } \\
\text { two SBT groups }\end{array}$ & $\begin{array}{l}p \text { value }^{2} \text { between } \\
\text { all three groups }\end{array}$ \\
\hline Joint pain & $20(54.05 \%)$ & $12(85.70 \%)$ & $7(77.78 \%)$ & $39(65.0 \%)$ & 0.053 & 0.080 \\
\hline Palpable spleen & $26(70.27 \%)$ & $7(50.0 \%)$ & $3(33.33 \%)$ & $36(60.0 \%)$ & 0.204 & 0.086 \\
\hline $\begin{array}{l}\text { Hospital admission } \\
\text { due to pain }\end{array}$ & $20(54.05 \%)$ & $10(71.43 \%)$ & $5(55.56 \%)$ & $35(58.33 \%)$ & 0.346 & 0.562 \\
\hline Jaundice & $14(37.84 \%)$ & $9(64.28 \%)$ & $6(66.67 \%)$ & $29(48.33 \%)$ & 0.120 & 0.109 \\
\hline Major infections & $13(35.14 \%)$ & $4(28.57 \%)$ & $4(44.44 \%)$ & $21(35.0 \%)$ & 0.749 & 0.744 \\
\hline Recurrent headaches & $11(29.73 \%)$ & $1(7.14 \%)$ & $2(22.22 \%)$ & $14(23.33 \%)$ & 0.142 & 0.281 \\
\hline Pica & $6(16.22 \%)$ & $3(21.43 \%)$ & $2(22.22 \%)$ & $11(18.33 \%)$ & 0.692 & 0.711 \\
\hline Abdominal pain & $6(16.22 \%)$ & $4(28.57 \%)$ & 0 & $10(16.67 \%)$ & 0.432 & 0.217 \\
\hline Dactylitis & $3(8.11 \%)$ & $3(21.43 \%)$ & $4(44.44 \%)$ & $10(16.67 \%)$ & 0.327 & $0.027^{*}$ \\
\hline Gallstones & $6(16.22 \%)$ & $3(21.43 \%)$ & $1(11.11 \%)$ & $10(16.67 \%)$ & 0.692 & 0.888 \\
\hline Pallor & $4(10.81 \%)$ & $2(14.28 \%)$ & $3(33.33 \%)$ & $9(15.0 \%)$ & 0.661 & 0.220 \\
\hline Acute chest syndrome & $3(8.11 \%)$ & $3(21.43 \%)$ & $2(22.22 \%)$ & $8(13.33 \%)$ & 0.327 & 0.290 \\
\hline Vision impairment & $8(21.62 \%)$ & 0 & 0 & $8(13.33 \%)$ & 0.088 & 0.074 \\
\hline Abdominal distension & $3(8.11 \%)$ & $1(7.14 \%)$ & $1(11.11 \%)$ & $5(8.33 \%)$ & 1.000 & 1.000 \\
\hline Facial deformities & $1(2.70 \%)$ & $2(14.28 \%)$ & 0 & $3(5.0 \%)$ & 0.179 & 0.189 \\
\hline Nocturnal enuresis & $2(5.40 \%)$ & $1(7.14 \%)$ & 0 & $3(5.0 \%)$ & 1.000 & 1.000 \\
\hline Leg ulcers & $2(5.40 \%)$ & $1(7.14 \%)$ & 0 & $3(5.0 \%)$ & 1.000 & 1.000 \\
\hline
\end{tabular}

${ }^{1}$ Fisher's exact test $p<0.05$ was taken as significant between two SBT groups

${ }^{2}$ Fisher's exact test $p<0.05$ was taken as significant between all three groups

There have been several island wide's surveys of anaemia conducted in Sri Lanka and in a nationwide study involving 7526 adolescent age school children conducted in 2009-2010 anaemia prevalence was 172 (5.6\%) in males and $298(11.1 \%)$ in female children. In the same survey $28(1.0 \%)$ male and $130(4.6 \%)$ female students were found to have Iron deficiency anaemia. Further analysis of the same study identified that $\beta$ thalassaemia trait and deletional $\alpha$ thalassaemia contributed to anaemia in a further $3 \%$. Eleven children with Sickle cell trait had been identified in this study but there is no mention about their haemoglobin level [4, 31-33]. Though anaemia is identified to be an important finding in the present study, it is unlikely that SCD has a significant bearing on the national anaemia figures due to its relative low prevalence.

Table 3 Presence and frequency of Hb F determining variants in Sri Lankan SCD patients

\begin{tabular}{|c|c|c|c|c|c|}
\hline Locus & Variants & Position on chromosome & Allele change & Genotypes detected & $\mathrm{Hb} \mathrm{F}$ boosting allele (Frequency) \\
\hline \multicolumn{6}{|l|}{ Chromosome 2} \\
\hline \multirow[t]{4}{*}{ BCL11A } & rs6545816 & $60,568,365$ & $A>C$ & $C C, n=37$ & C (88\%) \\
\hline & & & & $\mathrm{AC}, n=14$ & \\
\hline & rs1427407 & $60,571,547$ & $G>T$ & $\mathrm{GG}, n=43$ & $\mathrm{~T}(12 \%)$ \\
\hline & & & & $\mathrm{GT}, n=14$ & \\
\hline \multicolumn{6}{|l|}{ Chromosome 6} \\
\hline \multirow[t]{2}{*}{ HMIP-2A } & rs66650371 & $135,460,326-135,460,328$ & In > Del & $\begin{array}{l}\|, n=52 \\
\mathrm{Dl}, n=5\end{array}$ & Del (6\%) \\
\hline & & & & $\mathrm{DD}, n=1$ & \\
\hline \multirow[t]{2}{*}{ HMIP-2B } & rs9402686 & $135,469,509$ & $G>A$ & $\mathrm{GG}, n=52$ & A (4\%) \\
\hline & & & & $\mathrm{GA}, n=4$ & \\
\hline \multicolumn{6}{|l|}{ Chromosome 11} \\
\hline \multirow[t]{2}{*}{$X m n 1-H B G 2$} & rs7482144 & $5,232,745$ & $G>A$ & $\mathrm{GG}, n=4$ & A (47\%) \\
\hline & & & & $\mathrm{GA}, n=56$ & \\
\hline
\end{tabular}




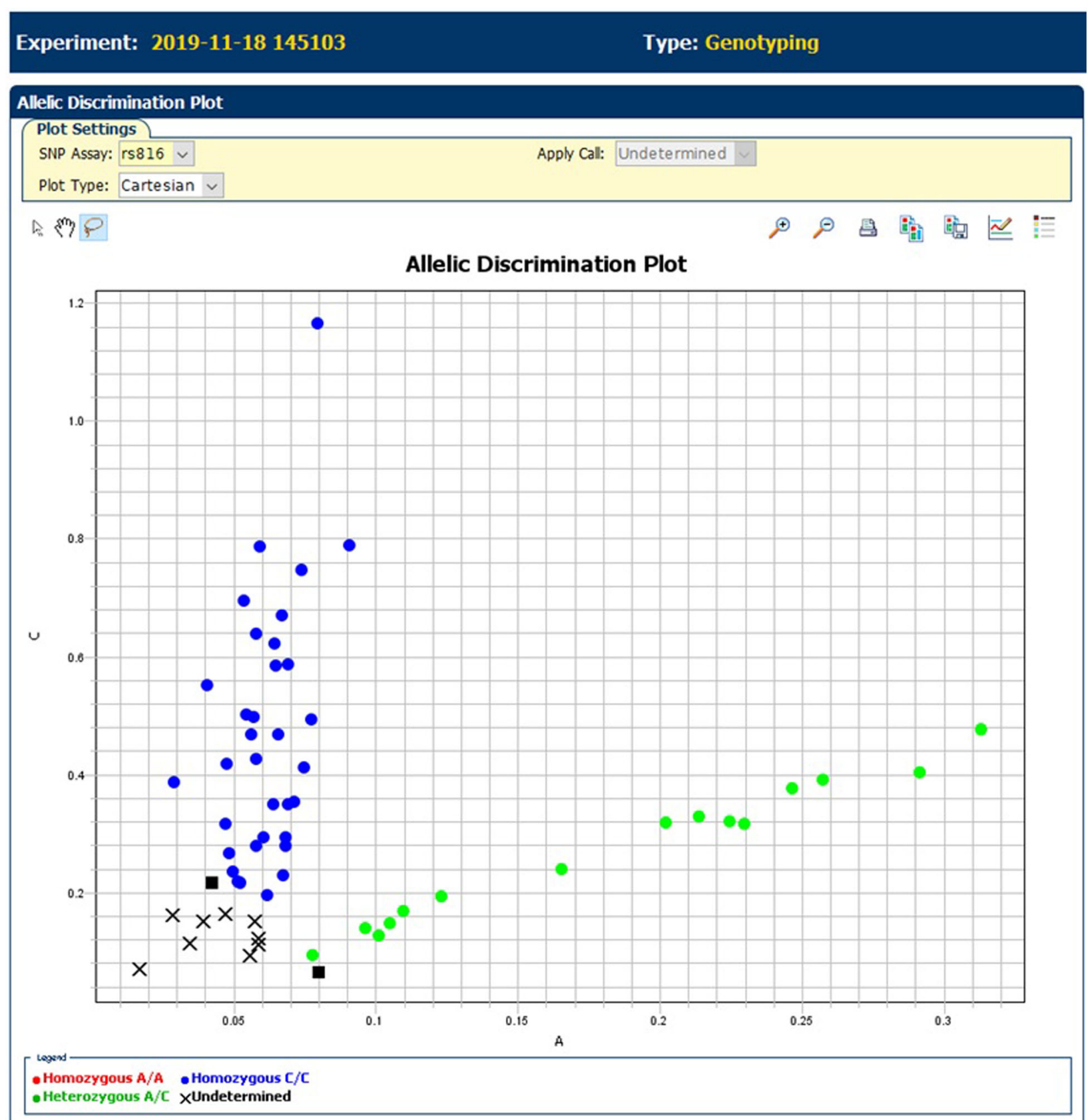

Fig. 2 Allelic discrimination of the marker Hb F marker rs6545816 of SCD patients

Joint pain was the most common clinical feature observed among $\mathrm{Hb}$ SS (77.78\%), severe $\mathrm{Hb} S / \beta+(54.05 \%)$ and $\mathrm{Hb} \mathrm{S} / \beta^{0}(85.70 \%)$ patients. Joint pains are not uncommon among sickle patients in the Indian subcontinent. A recent study from Madhya Pradesh, Central India reported that the incidence of joint pain is over $80 \%$ in both $\mathrm{Hb}$ SS and SBT groups [34]. Bone pain reported at high frequencies in Indian SCD patients [24, 25, 35], was not present in any participants in our study. Requirement for regular blood transfusions was higher among
$\mathrm{Hb} S \mathrm{SS}(33.33 \%)$ than severe $\mathrm{Hb} \mathrm{S} / \beta+(2.70 \%)$ and $\mathrm{Hb} \mathrm{S} /$ $\beta^{0}(14.30 \%)$ patients in the present study. These findings differ from a study reported from Madhya Pradesh (India) in which $16.1 \%$ of $\mathrm{Hb}$ SS and $17.4 \%$ of SBT patients were on regular blood transfusion [34]. Furthermore, seven severe $\mathrm{Hb} S / \beta+(18.90 \%)$ and $5 \mathrm{Hb} S / \beta^{0}$ $(35.70 \%)$ patients had never received a transfusion in their lifetime. As the indication for blood transfusions were very often physician initiated and there was no defined rationale, these observations need to be interpreted 
with caution, and suggests the need for clear guidelines on the management of SCD in Sri Lanka, including the use of transfusion.

Only two cases of avascular necrosis of the hip were reported in the present study, which is in contrast to eastern Indian SCD patients, in whom incidences over $10 \%$ have been reported across several age groups [26]. Priapism and leg ulcers were not found in our study. There were no deaths in any of the SCD patients reported during the period of observation.

$\mathrm{Hb} \mathrm{F}$ plays a significant role in ameliorating complications is SCD [36]. In the present study, in patients who were not on transfusion, mean $\mathrm{Hb} F$ concentrations were $24.4 \%, 23.7 \%$ and $21.2 \%$ in $\mathrm{Hb} \mathrm{SS}$, severe $\mathrm{Hb} \mathrm{S} / \beta+$ and $\mathrm{Hb}$ $\mathrm{S} / \beta^{0}$ patients, respectively. These values are in accordance with the observations from the Maharashtra (India) but are higher than the values observed in Madhya Pradesh (India) $[25,34]$. The Hb F levels are much higher than those found in SCD patients of Sub-Saharan African origin, and levels greater than $20 \%$ would typically be associated with less severe clinical picture. $\mathrm{Hb} \mathrm{F}$ boosting allele "C" of rs6545816 was detected at a much higher frequency in Sri Lankan patients than in patients from the United Kingdom (34\%), Tanzania (36\%) and Nigeria (35\%) $[18,19]$. Furthermore, among those who were not on transfusion and hydroxyurea $(n=22)$, "T" allele of rs1427407 was significantly associated with high $\mathrm{Hb} F$ levels $(p$ 0.046). The presence of common $\alpha+$ gene deletions was surprisingly low in this study. This is in contrast with observations in Western Indian SCD patients in whom the prevalence of $\alpha$ gene deletions was 29/ $51 ; 56.8 \%$ [19]. Similarly, in a study of 60 SCD patients in New Delhi, the prevalence of $\alpha$ globin gene deletions was $18 / 60 ; 30 . \%$ [37].

One of the most notable observational findings of our study was the gross inconsistency in the clinical management of SCD patients across the different centres across Sri Lanka. Usage of hydroxyurea was not consistent among sickle patients in these centres. Equally, the practice of blood transfusions was also very variable, reflecting perhaps the lack of familiarity in the management of the disease by the attending medical teams and the need for national guidelines on the management of patients with SCD. The prevalence of SCD in Sri Lanka however is rare permitting us to gather data from only $60 \mathrm{SCD}$ patients which is a limitation in the present study.

\section{Conclusions}

Overall, though the numbers may be limited the clinical course of the Asian version of SCD in Sri Lanka appears to be milder than that described from India. High $\mathrm{Hb} F$ levels are common and deletional $\alpha$ thalassaemia rarer. The natural selection, early migratory patterns of Arabs and settlements may explain why SCD is found mostly in coastal regions and low lands of Sri Lanka. We plan to undertake further work to elucidate the causative elements responsible for the milder appearance of SCD in Sri Lanka.

\section{Abbreviations \\ SCD: Sickle Cell Disease; HBB: $\beta$-haemoglobin subunit; Hb S: Sickle Haemoglobin; Hb SS: Homozygous Sickle Cell Anaemia; SBT: Sickle $\beta$ - thalassaemia; EDTA: Ethylenediaminetetraacetic acid; CE: Capillary Electrophoresis; PCR: Polymerase Chain Reaction; RFLP: Restriction Fragment Length Polymorphism; ARMS: Amplification Refractory Mutation System; NGS: New Generation Sequencing; Hb F: Foetal Haemoglobin}

\section{Acknowledgements}

Not applicable.

\section{Authors' contributions}

TD has contributed to haplotype sickle haemoglobin with RFLP, total data curation, analyze the data and write the original manuscript. AP has contributed to design the research, clinical data collection, supervise the overall work and to revise and edit the manuscript. DR, AA and AM have contributed to revise and edit the manuscript. FS has contributed to NGS of $\mathrm{Hb}$ SS patients, SM has contributed to genotyping of Hb F markers, RR has contributed to Gap PCR of common a plus gene deletions and ARMS PCR for $\beta$-thalassaemia mutations, DB, UN, US, YC, KP, SP, SB, CE, PD, MW and AAA have contributed to clinical data collection and edit the manuscript. The author(s) read and approved the final manuscript.

\section{Funding}

This research was funded by National Research Council Sri Lanka, grant number NRC 16-001 and The APC was not funded by any funding agency.

\section{Availability of data and materials}

The datasets used and/or analyzed during the current study are available from the corresponding author on reasonable request.

\section{Ethics approval and consent to participate}

Ethical approval for the study was obtained from Faculty of Medicine, University of Kelaniya, Sri Lanka (P/01/01/2016). Informed written consents form adult SCD patients and assents from the parents of the participating SCD children were obtained before enrollment for the present study.

Consent for publication

Not applicable.

\section{Competing interests}

All authors declare that they have no competing interests.

\section{Author details}

${ }^{1}$ Department of Medical Laboratory Sciences, University of Sri Jayewardenepura, Nugegoda, Sri Lanka. ${ }^{2}$ National Thalassaemia Centre, Teaching Hospital, Kurunegala, Sri Lanka. ${ }^{3}$ Department of Pediatrics, Teaching Hospital, Kurunegala, Sri Lanka. ${ }^{4}$ Thalassaemia Unit, Teaching Hospital, Anuradhapura, Sri Lanka. ${ }^{5}$ Department of Haematology, Teaching Hospital, Ragama, Sri Lanka. ${ }^{6}$ Department of Pediatrics, District General Hospital, Matara, Sri Lanka. ${ }^{7}$ Department of Pediatrics, District General Hospital, Hambantota, Sri Lanka. ${ }^{8}$ Department of Haematology, District General Hospital, Monaragala, Sri Lanka. ${ }^{9}$ Department of Haematology, Teaching Hospital, Batticaloa, Sri Lanka. ${ }^{10}$ Department of Haematology, District General Hospital, Ampara, Sri Lanka. ${ }^{11}$ Department of Pediatrics, District General Hospital, Ampara, Sri Lanka. ${ }^{12}$ Department of Clinical Sciences, Eastern University, Batticaloa, Sri Lanka. ${ }^{13}$ Thalassaemia Adult and Adolescent Care Centre, Teaching Hospital, Ragama, Sri Lanka. ${ }^{14}$ Molecular Medicine Unit, University of Kelaniya, Ragama, Sri Lanka. ${ }^{15}$ Molecular Pathology Department, Viapath at King's College Hospital, London, UK. ${ }^{16}$ Weatherall Institute of Molecular Medicine, University of Oxford, Oxford, UK. ${ }^{17}$ School of Cancer and Pharmaceutical Sciences, The Rayne Institute, King's College London, London, UK. ${ }^{18}$ Department of Haematological Medicine, King's College Hospital, London, UK. ${ }^{19}$ Department of Medicine, University of Kelaniya, Ragama, Sri Lanka. 
Received: 13 February 2020 Accepted: 29 June 2020

Published online: 06 July 2020

\section{References}

1. Kato GJ, Piel FB, Reid CD, Gaston MH, Ohene-Frempong K, Krishnamurti L, et al. Sickle cell disease. Nature Reviews Disease Primers. 2018;4:18010.

2. Lanka DS-S. Census of population and housing (table A3). Sri Lanka; 2012.

3. De Silva CC, Bulugahapitiya TD, De Silva J, Wickremasinghe RL, Jonxis HP. Sinhalese family with haemoglobin S. Br Med J. 1962;1(5291):1519-21.

4. Premawardhena A, Allen A, Piel F, Fisher C, Perera L, Rodrigo R, et al. The evolutionary and clinical implications of the uneven distribution of the frequency of the inherited haemoglobin variants over short geographical distances. Br J Haematol. 2017:176(3):475-84.

5. Lucas GN, Jayawardena DR. A case of homozygous sickle cell disease in Sri Lanka. Ceylon Med J. 1991;36(4):172-4.

6. Thalagahage $\mathrm{KH}$, Jayaweera J, Kumbukgolla W, Perera N, Thalagahage E, Kariyawasam J, et al. HbS/D-Punjab disease: report of 3 cases from Sri Lanka. Indian J Hematol blood Transfusion. 2018;34(2):350-2.

7. Tudawe MN, Senadheera NB, Gooneratne LV. Variations in the presentation of sickle cell beta thalassaemia--a report of two cases. Ceylon Med J. 2005; 50(3):134-5

8. Nagaratnam N. Hemoglobinopathies in Sri Lanka and their anthropological implications. Hemoglobin. 1989;13(2):201-11.

9. Karunatilake $H$, Vithiya K, Malavan $\mathrm{R}$, Natalia $\mathrm{H}$, Ratnayake $\mathrm{H}$. Exchange transfusion for intrahepatic cholestasis due to sickle beta thalassaemia. Ceylon Med J. 2009:54(3):95-6.

10. Premathilaka LHRA, Lakmini MS, Darshana LGT, Nawaratne SB, Mettananda S, De Silva S, et al. Stroke in sickle beta thalassemia - a case report highlighting pitfalls in management in a low prevalence country. Sri Lanka J Med. 2018;26:55.

11. Premawardhana AP, Mudiyanse R, De Silva ST, Jiffry N, Nelumdeniya U, de Silva $U$, et al. A nationwide survey of hospital-based thalassemia patients and standards of care and a preliminary assessment of the national prevention program in Sri Lanka. PLoS One. 2019;14(8):e0220852.

12. Fisher CA, Premawardhena A, de Silva S, Perera G, Rajapaksa S, Olivieri NA et al. The molecular basis for the thalassaemias in Sri Lanka. Br J Haematol. 2003:121(4):662-71.

13. Rahimi Z, Karimi M, Haghshenass M, Merat A. Beta-globin gene cluster haplotypes in sickle cell patients from Southwest Iran. Am J Hematol. 2003; 74(3):156-60.

14. Steinberg MH, Hsu H, Nagel RL, Milner PF, Adams JG, Benjamin L, et al. Gender and haplotype effects upon hematological manifestations of adult sickle cell anemia. Am J Hematol. 1995:48(3):175-81.

15. Chong SS, Boehm CD, Higgs DR, Cutting GR. Single-tube multiplex-PCR screen for common deletional determinants of alpha-thalassemia. Blood. 2000;95(1):360-2.

16. Old JM, Khan SN, Verma I, Fucharoen S, Kleanthous M, loannou P, et al. A multi-center study in order to further define the molecular basis of betathalassemia in Thailand, Pakistan, Sri Lanka, Mauritius, Syria, and India, and to develop a simple molecular diagnostic strategy by amplification refractory mutation system-polymerase chain reaction. Hemoglobin. 2001; 25(4):397-407.

17. Bhanushali AA, Patra PK, Nair D, Verma H, Das BR. Genetic variant in the BCL11A (rs1427407), but not HBS1-MYB (rs6934903) loci associate with fetal hemoglobin levels in Indian sickle cell disease patients. Blood Cells Mol Dis. 2015:54(1):4-8

18. Gardner K, Fulford T, Silver $N$, Rooks $H$, Angelis N, Allman M, et al. G (HbF): a genetic model of fetal hemoglobin in sickle cell disease. Blood Adv. 2018; 2(3):235-9.

19. Adeyemo TA, Ojewunmi OO, Oyetunji IA, Rooks H, Rees DC, Akinsulie AO, et al. A survey of genetic fetal-haemoglobin modifiers in Nigerian patients with sickle cell anaemia. PLoS One. 2018;13(6):e0197927 e.

20. Thein SL. The molecular basis of $\beta$-thalassemia. Cold Spring Harb Perspect Med. 2013;3(5):a011700 a

21. Weatherall DJ, Clegg JB. The thalassaemia syndromes, vol. xiv. 4th ed. Oxford: Blackwell Science; 2001. p. 846.

22. Bohara V, Raut L, Badarkhe G, Roy SS, Chaudhuri U. Homozygosity for the severe beta(+)-thalassemia mutation [IVS-I-5 (G>C)] causes the phenotype of thalassemia trait: an extremely rare presentation. Hemoglobin. 2013;37(1): $101-5$.
23. HbVar: A database of Human Hemoglobin Variants and Thalassemias [Internet]. HbVar. 2001. Available from: http://globin.bx.psu.edu/cgi-bin/ hbvar/query_vars3?mode=output\&display_format=page\&i=824. Accessed 8 May 2020.

24. Kulozik AE, Bail S, Kar BC, Serjeant BE, Serjeant GE. Sickle cell-beta+ thalassaemia in Orissa state, India. Br J Haematol. 1991;77(2):215-20.

25. Jain D, Warthe V, Dayama P, Sarate D, Colah R, Mehta P, et al. Sickle cell disease in Central India: a potentially severe syndrome. Indian J Pediatr. 2016:83(10):1071-6.

26. Mashon RS, Dash PM, Khalkho J, Dash L, Mohanty PK, Patel S, et al. Higher fetal hemoglobin concentration in patients with sickle cell disease in eastern India reduces frequency of painful crisis. Eur J Haematol. 2009;83(4): 383-4.

27. Shaikho EM, Farrell JJ, Alsultan A, Qutub H, Al-Ali AK, Figueiredo MS, et al. A phased SNP-based classification of sickle cell anemia HBB haplotypes. BMC Genomics. 2017;18(1):608.

28. Jastaniah W. Epidemiology of sickle cell disease in Saudi Arabia. Ann Saudi Med. 2011:31(3):289-93.

29. Alsultan A, Alabdulaali MK, Griffin PJ, Alsuliman AM, Ghabbour HA Sebastiani P, et al. Sickle cell disease in Saudi Arabia: the phenotype in adults with the Arab-Indian haplotype is not benign. Br J Haematol. 2014; 164(4):597-604.

30. Dasanayaka R. Muslim Trade Relations with Sri Lanka: Historical RespectiveIn Sinhala: Ada Sanda Saha Tharadiya; 2019.

31. Allen A, Allen S, Rodrigo R, Perera L, Shao W, Li C, et al. Iron status and anaemia in Sri Lankan secondary school children: A cross-sectional survey. PLoS One. 2017;12(11):e0188110 e.

32. Premawardhena A, Perera PS. Anaemia in Sri Lanka: the missing pieces. Ceylon Med J. 2018;63(3):105-7.

33. Rodrigo R, Allen A, Manampreri A, Perera L, Fisher CA, Allen S, et al. Haemoglobin variants, iron status and anaemia in Sri Lankan adolescents with low red cell indices: a cross sectional survey. Blood Cells Mol Dis. 2018, 71:11-5.

34. Yadav R, Lazarus M, Ghanghoria P, Singh M, Gupta RB, Kumar S, et al. Sickle cell disease in Madhya Pradesh, Central India: A comparison of clinical profile of sickle cell homozygote vs. sickle-beta thalassaemia individuals. Hematology (Amsterdam, Netherlands). 2016;21(9):558-63.

35. Patel J, Patel B, Serjeant GR. The bone pain crisis of sickle cell disease and malaria: observations from Gujarat, India. Indian J Community Med. 2017; 42(3):167-9.

36. Piel FB, Steinberg MH, Rees DC. Sickle cell disease. N Engl J Med. 2017; 376(16):1561-73.

37. Pandey S, Pandey S, Mishra RM, Sharma M, Saxena R. Genotypic influence of a-deletions on the phenotype of Indian sickle cell anemia patients. Korean Hematol. 2011;46(3):192-5.

\section{Publisher's Note}

Springer Nature remains neutral with regard to jurisdictional claims in published maps and institutional affiliations.

Ready to submit your research? Choose BMC and benefit from:

- fast, convenient online submission

- thorough peer review by experienced researchers in your field

- rapid publication on acceptance

- support for research data, including large and complex data types

- gold Open Access which fosters wider collaboration and increased citations

- maximum visibility for your research: over $100 \mathrm{M}$ website views per year

At BMC, research is always in progress.

Learn more biomedcentral.com/submissions 